\title{
Faktore wat die werkverrigting van rekenaargebaseerde inligtingstelsels beinvloed
}

\author{
Dr. P.J.S. Bruwer \\ Departement Rekenaarwetenskap en Nagraadse Skool vir Bestuurswese, PU vir CHO
}

\begin{abstract}
Factors which influence computer-based information systems. The design and implementation of computer-based information systems have for a long time (and in some organizations are still being) accepted as primarily technical activities. As a result of this attitude about technology, the fact that practical. ly all computer-based systems exist within the context of an organization has been largely ignored. From the literature it has emerged that many computer-based information systems have failed, not necessarily as a result of poor technical quality, but because certain other important aspects, which deter. mine the success or the failure of a computer-based system have been left out of account. As a result of a research project, it will be shown in this paper which factors are the most important in their contribution to the success of computerbased systems.
\end{abstract}

S. Afr. J. Bus. Mgmt. 1983, 14: 6-10

Die ontwerp en bedryf van rekenaargebaseerde inligtingstelsels is baie lank (en in sommige organisasies vandag nog) aanvaar as primér tegniese aktiwiteite. As gevolg van hierdie houding oor tegnologie is die feit dat feitlik alle rekenaargebaseerde inligtingstelsels in die konteks van 'n organisasie bestaan, geheel en al geīgnoreer. Uit die literatuur blyk dit dat talle rekenaargebaseerde inligtingstelsels misluk het en nie noodwendig as gevolg van swak tegniese kwaliteit nie, maar omdat daar ander belangrike faktore, wat die sukses of mislukking van 'n gerekenariseerde stelsel bepaal, buite rekening gelaat is.

In hierdie artikel word daar op grond van die resultate van 'n navorsingsprojek' wat uitgevoer is, aangetoon watter faktore die grootste bydrae tot die sukses van rekenaargebaseerde inligtingstelsels lewer.

S.Afr. Tyoskr. Bodrytsl. 1983, 14: 6- 10

\section{Inleiding}

Oor die afgelope dekade is 'n groot aantal rekenaarstelsels vir 'n bree spektrum van toepassings deur privaat sowel as openbare organisasies in gebruik geneem. So 'n verandering waar daar van die konvensionele handstelselmetodes oorgeskakel is na get ekenariseerde stelsels hou nie slegs groot finansiële implikasies vir ' $n$ onderneming in nie, maar het ook organisatoriese veranderinge tot gevolg. Dit is die bestuur van die organisasie wat moet besluit:

(a) of 'n rekenaar gebruik gaan word en hoe dit aangewend gaan word;

(b) watter organisatoriese veranderinge nodig word wanneer daar gerekenariseer word, en

(c) dit is ook die bestuur wat moet toesien dat hierdie veranderinge wel gemaak word.

Vele probleme kan egter ook verwag word met die koms van ' $n$ rekenaar en die rekenarisering van handstelsels in ' $n$ organisasie - so veel so dat talle gerekenariseerde stelsels vandag tot mislukking gedoem is.

Die doel van die navorsing kan kortliks in vier hoof punte saamgevat word, naamlik:

(i) om die gebruik van gerekenariseerde inligtingstelsels en die welslae daarvan soos dit deur die gebruiker waargeneem word, te ondersoek;

(ii) om vas te stel watter faktore die grootste bydrae lewer tot die sukses van gerekenariseerde stelsels;

(iii) om deur middel van optimaliseringsmetodes vas te stel watter faktore die belangrikste is om te verander sodat die welslae optimaal verhoog kan word, en

(iv) om modelle te formuleer waardeur dit vir die bestuur van 'n organisasie moontlik sou wees om kapitaal so aan te wend dat die gerekenariseerde stelsels optimale werkverrigting lewer.

In paragraaf een word die hipotetiese navorsingsmodel $^{1, p .134}$ kortliks bespreek. Daarna word die kriterium vir sukses wat in hierdie projek gebruik is, in paragraaf twee verduidelik. In paragraaf drie word die metode wat gevolg is met die insameling van die data bespreek en in paragraaf vier die lineêre verbande wat ondersoek is. 'n Voorbeeld van die resultate word in paragraaf vyf gegee, gevolg deur 'n kort bespreking van die kanoniese korrelasietoets in paragraaf ses. Die resultate word in paragraaf sewe bespreek en in paragrawe agt en nege word die beperkte lineêre regressiemetode en die kostemodel kortliks bespreek. 


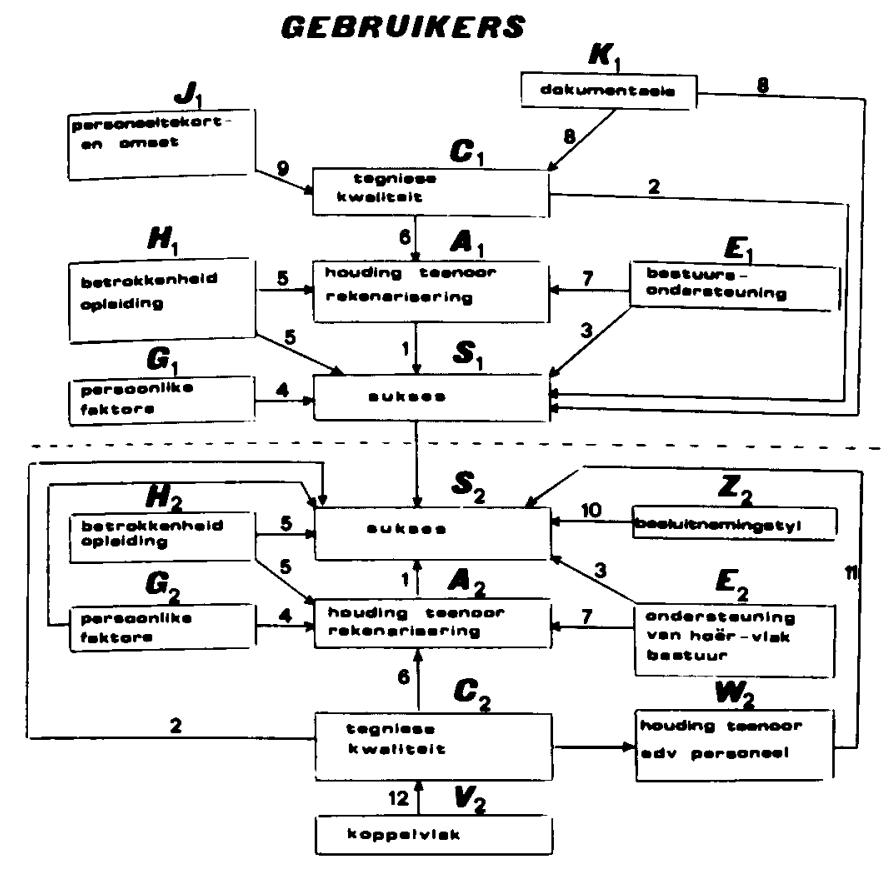

BESTUUR

Figuur 1 Hipotetiese navorsingsmodel

\section{Hipotetiese navorsingsmodel}

Deur 'n beskrywende model van veranderlikes ${ }^{1, p .129}$ (Figuur 1) te gebruik, is daar met behulp van BMDP-programmatuur $^{2}$ korrelasie- en regressiemetodes gebruik om ondersoek in te stel na lineêre verbande tussen sekere veranderlikes in die model (paragraaf 4). Die sleutelveranderlikes in die model, wat uit 'n gebruikers- en bestuurderskomponent bestaan, is sukses van gerekenariseerde stelsels. Merk op dat in die model en die bespreking verder die simbole $K_{1}, C_{1}$, ens. gebruik is vir ' $n$ korter skryfwyse vir die veranderlikes soos beskryf in die ooreenstemmende blokkie in die diagram. 'n Onderskrif 1 saam met die veranderlike simbool dui op veranderlikes wat betrekking het op gewone gebruikers, terwyl die onderskrif 2 dui op veranderlikes wat op die bestuur van die organisasie betrekking het.

\section{Kriteria vir sukses}

Die volgende drie kriteria kan gebruik word om die sukses van gerekenariseerde stelsels mee te meet:

(i) kostevoordeel;

(ii) mate van gebruik;

(iii) gebruikerstevredenheid

(i) is 'n baie doeltreffende kriterium, maar moeilik om te gebruik, aangesien daar ook onmeetbare en/of ontasbare voordele uit rekenarisering verkry kan word.

(ii) kan slegs gebruik word wanneer die gebruik van die stelsels vrywilliglik is.

In hierdie navorsingsprojek' is gebruikerstevredenheid as maatstaf vir die sukses van stelsels gebruik.

\section{Insameling van data}

In Figuur 1 word die verbande tussen die verskillende veranderlikes met gerigte lynstukke aangedui wat genommer is ooreenkomstig die hipoteses wat getoets is en in die volgende paragraaf gegee word. Om hierdie verbande te ondersoek is data in 'n baie groot organisasie ingesamel. In die organisasie is daar sowat 140 gerekenariseerde stelsels wat deur nagenoeg 1200 klerklike of lae-vlak gebruikers en deur 114 bestuurders gebruik word. (Die organisasie verkies om anoniem te bly.)

Vraelyste is ontwerp vir die klerklike gebruikers sowel as vir die bestuurders en ' $n$ steekproef van 200 gewone gebruikers en die volle populasie bestuurders is in die ondersoek betrek. Die oorgrote meerderheid vrae ${ }^{1, p .282}$ moes op 'n 7-puntskaal beantwoord word. Die doel van hierdie vrae was om die veranderlikes in die model (Figuur 1) te kwantifiseer.

\section{Verbande wat ondersoek is}

Deur van korrelasies, faktorontleding, kanoniese korrelasie en stapsgewyse lineêre regressie gebruik te maak ${ }^{1, p .157}$ kon aangetoon word dat die volgende lineêre verbande bestaan:

1. gebruikerhouding teenoor rekenarisering en die sukses van gerekenariseerde stelsels;

2. die tegniese kwaliteit van 'n gerekenariseerde stelsel en die sukses van die stelsel;

3. bestuursondersteuning en die sukses van 'n gerekenariseerde stelsel;

4. persoonlike faktore aan die kant van die gebruiker en die sukses van 'n gerekenariseerde stelsel;

5. gebruikersbetrokkenheid in die ontwerp, ontwikkeling, implementering en bedryf van 'n gerekenariseerde stelsel en die houding van die gebruiker teenoor en die sukses van 'n gerekenariseerde stelsel;

6. die tegniese kwaliteit van 'n gerekenariseerde stelsel en die houding van die gebruiker teenoor rekenarisering;

7. bestuursondersteuning en die houding van die gebruiker teenoor rekenarisering;

8. dokumentasie en gebruikersopleiding en die tegniese kwaliteit en sukses van gerekenariseerde stelsels;

11. die houding van bestuur teenoor rekenaarpersoneel en die sukses van 'n gerekenariseerde stelsel;

12. die mens/stelsel koppelvlak en die tegniese kwaliteit van 'n gerekenariseerde stelsel, en

13. die beskikbaarheid van hulpbronne en die sukses van gerekenariseerde stelsels.

Merk op dat die nommers van die hipoteses ooreenstem met die nommers in Figuur 1. Verder is hipotese 9 nie statisties getoets nie omdat verskeie organisasies in so 'n geval betrek sou moes word. Ook is hipotese 10 nie getoets nie, omdat dit opsigself 'n uitgebreide navorsingsprojek is. Verder het hipotese 13 voortgespruit uit die verwerking van die data en is hierdie hipotese nie aanvanklik in die hipotetiese navorsingsmodel opgeneem nie.

Die bestuur en die klerklike gebruikers is as twee groepe gebruikers behandel omdat die gebruik van gerekenariseerde stelsels in die twee groepe radikaal van mekaar verskil. Verskeie veranderlikes is gebruik om 'n hoofveranderlike (soos byvoorbeeld die tegniese kwaliteit van gerkenariseerde stelsels) in die model mee te meet.

\section{Voorbeeld}

As voorbeeld word die pare korrelasiekoeffisiente wat gebruik is om hipotese 1 te ondersoek en die kanoniese korrelasie vir gebruikershouding $\left(A_{1}\right)$ teenoor die sukses $\left(S_{1}\right)$ 
Tabel 1 Pearson korrelasiekoeffisiente

\begin{tabular}{llllllllllll}
\hline & $A_{1,1}$ & $A_{1,2}$ & $A_{1,3}$ & $A_{1,4}$ & $A_{1,9}$ & $A_{1,6}$ & $A_{1,7}$ & $A_{1,8}$ & $A_{1,9}$ & $A_{1,10}$ \\
\hline$S_{1,1}$ & $\mathbf{0 , 0 8}$ & $\mathbf{0 , 0 0}$ & $0,26^{++}$ & 0,13 & 0,07 & 0,13 & 0,22 & 0,08 & $0,20^{+}$ & $0,14^{+}$ \\
$S_{1,2}$ & $0,32^{++}$ & 0,05 & $0,45^{++}$ & $0,28^{++}$ & 0,10 & $0,30^{++}$ & $0,14^{+}$ & $0,24^{++}$ & $0,30^{++}$ & $0,17^{+}$ \\
$S_{1,3}$ & $0,29^{+}$ & 0,11 & $0,15^{+}$ & $0,22^{++}$ & 0,05 & $0,23^{++}$ & $0,38^{+}$ & $0,15^{+}$ & $0,29^{+}$ & $0,20^{++}$ \\
$S_{1,4}$ & $0,31^{+}$ & 0,31 & $0,17^{+}$ & $0,41^{++}$ & $0,20^{++}$ & $0,26^{++}$ & $0,41^{++}$ & 0,12 & $0,30^{+}$ & 0,01 \\
\hline
\end{tabular}

Tabel 2 Kanoniese korrelasietabel

\begin{tabular}{|c|c|c|c|c|}
\hline & $\begin{array}{l}\text { Kanoniese } \\
\text { korrelasie }\end{array}$ & Eiewaarde & $X_{0.05 ; 8, m, n}$ & $X_{0.01 ;, m, \mathrm{~m}}$ \\
\hline$S_{1}: A_{1}$ & 0,61 & $0,37^{+}$ & 0.155 & 0,18 \\
\hline
\end{tabular}

van gerekenariseerde stelsels in Tabelle 1 en 2 saamgevat. Die resultate in hierdie tabelle is afkomstig van die data van klerklike gebruikers. Tien houdingsveranderlikes $A_{1,1}$, $A_{1,2}, \ldots A_{1,10}$ is gebruik en vier suksesveranderlikes $S_{1,1}, S_{1,2}$, $S_{1,3}$ en $S_{1,4}$. Die eerste indeks van 'n veranderlike dui op bestuur of klerklik en die tweede op verskillende komponente van 'n hoofveranderlike.

Omdat die hipoteses wat uit die model gevolg het, egter betrekking het op lineêre verbande tussen hoofveranderlikes, is daar van kanoniese korrelasies gebruik gemaak om die hipoteses formeel te toets. Kanoniese korrelasies meet die graad van verwantskap tussen twee versamelings van veranderlikes $3, p .253$. Pare korrelasies tussen die afsonderlike veranderlikes is egter ook bereken en ontleed.

\section{Toets vir die onafhanklikheid van groepe veranderlikes}

Laat die hipotese wat getoets moet word, wees dat daar geen verband tussen twee groepe veranderlikes bestaan nie. Daar kan nou van 'n toets ${ }^{3, p .253}$ gebruik gemaak word waar die grootste kanoniese eiewaarde en 'n kritieke waarde gebruik word om op 'n voorgeskrewe peil van betekenis te toets of die hipotese geld. Indien die grootste kanoniese eiewaarde met $C_{1}$ aangedui word en die kritieke waarde met $X$;s,m,n, dan word die hipotese aanvaar indien

$C_{1} \leq X_{\alpha ; \mathbf{s}, \mathbf{m}, \mathbf{n},}$

waar

$\propto \quad=$ vlak van betekenis

$S=\min \{p, q\}$

$p, q=$ aantal veranderlikes in die twee versamelings respektiewelik

$m=\frac{|p-q|-1}{2}$

$n=\frac{N-p-q-2}{2}$

$N=$ aantal datapunte
Die grootste eiewaarde word verkry deur van die BMP6M ${ }^{2, p .727}$ programpakkie gebruik te maak en $X_{\alpha ; s, m, \mathrm{n}}$ word vanaf 'n tabel afgelees ${ }^{3, p .379}$.

\section{Bespreking van die resultate}

Uit Tabel 1 volg dat daar meer korrelasies is wat op 'n $1 \%$ peil van betekenis beduidend is, as wat daar is wat net op 'n $5 \%$ peil van betekenis beduidend is. Formeel word hipotese 1 deur die kanoniese korrelasietoets (paragraaf 6) verwerp. Dieselfde prosedure is gevolg met betrekking tot al tien ander hipoteses en dit is gedoen vir beide die bestuurdersgroep sowel as die klerklike groep gebruikers en ondersteuning vir al elf hipoteses is op hierdie wyse verkry.

Deur van faktorontleding ${ }^{4}$ gebruik te maak is die vier suksesveranderlikes van die klerklike gebruikers tot ' $n$ enkele faktor gekombineer ${ }^{2, B M D P 4 M . p .656}$ en deur middel van staps-

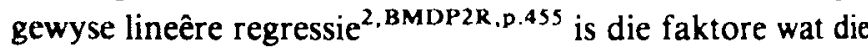
variasie van hierdie enkele suksesveranderlikes die beste verklaar, geselekteer. Die regressiemodel wat gevind is, was weer eens in ooreenstemming met die hipoteses wat gestel is.

Die bestuurdersdata is ook gebruik om ' $n$ lineêre regressiemodel te vind in terme waarvan die sukses verklaar kan word. Aangesien die volle populasie bestuurders in hierdie ondersoek betrek is en dit uiteindelik die bestuur is wat een of ander aksie moet onderneem wanneer die gerekenariseerde stelsels nie doeltreffend funksioneer nie, is hierdie model belangrik vir verdere ontleding.

Eerstens is ' $n$ faktorontleding op die twee veranderlikes wat gebruik is om die sukses van gerekenariseerde stelsels te meet, uitgevoer, sodat sukses deur middel van lineêre regressie as ' $n$ lineêre verband van ' $n$ aantal veranderlikes uitgedruk kan word. Deur van stapsgewyse lineêre regressie gebruik te maak, is die 39 onafhanklike veranderlikes in terme waarvan $S$ (sukses) verklaar kan word, gereduseer tot 18 veranderlikes. Hierdie veranderlikes het $72 \%$ van die variasie van $S$ verklaar. Deur van die uitvoer van die BMDP2R-program ${ }^{2, p .455}$ gebruik te maak is die aantal veranderlikes in die regressievergelyking uitgestip teenoor $R^{2}$ (Figuur 2).

Uit hierdie grafiek was dit duidelik dat 'n aantal onafhanklike veranderlikes relatief min tot $R^{2}$ bydra. Om die geldigheid van hierdie vermoede te ondersoek is 'n meervoudige lineêre regressieprogram (BMDP9R ${ }^{2, p .459}$ ) waar Mallows se $C_{\mathrm{p}}$ as kriterium gebruik word, gebruik om die 'beste' deelversameling van onafhanklike veranderlikes te selekteer in terme waarvan $S$ verklaar kan word; $69 \%$ van die variasie van $S$ is deur 12 veranderlikes in die 'beste' deelversameling verklaar. Hierdie 12 veranderlikes is sonder om enige prioriteitsvolgorde te gebruik, die volgende: 


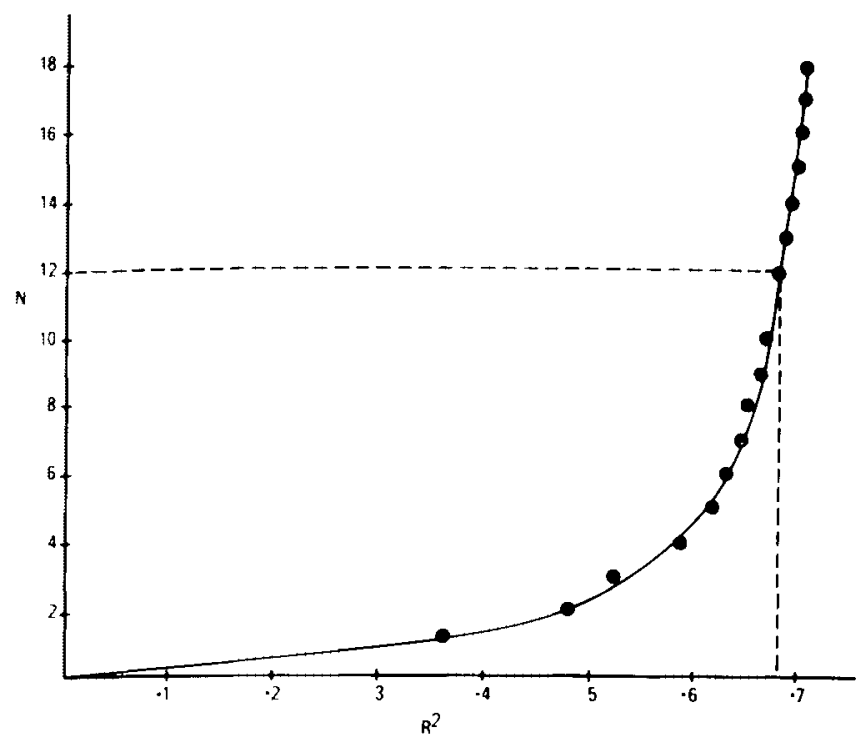

Figuur 2 Grafiese voorstelling van aantal veranderlikes $(N)$ teenoor $R^{2}$

- Bestuur se houding teenoor rekenarisering.

- Die ondersteuning van bestuur ten opsigte van rekenariseringsprojekte.

- Die graad van detail in uitvoerverslae (te veel).

- Die graad van detail in uitvoerverslae (te $\mathrm{min}$ ).

- Die akkuraatheid van inligting.

- Tyd wat bestuur betrokke was in rekenariseringsprojekte.

- Die dienstermyn van die bestuurders in die organisasie.

- Die beskikbaarheid van hulpbronne.

- Die tegniese bekwaamheid van rekenaarpersoneel.

- Die kwaliteit van die bestuurders se bestuursvernuf.

- Opleiding wat aan die gebruikers verskaf word ten opsigte van die gerekenariseerde stelsels wat hulle gebruik.

- Mate waartoe gebruikers betrek is in rekenariseringsprojekte.

\section{Beperkte lineêre regressiemodelmetode}

Deur 'n beperkte regressiemodelmetode ${ }^{1, p .187}$ te gebruik waarin daar van lineêre programmeringstegnieke gebruik gemaak is, kon die aantal onafhanklike veranderlikes in die lineêre regressiemodel verder verminder word.

Die resultaat van die toepassing van hierdie tegniek was dat daar vyf faktore uitkristaliseer het wat ' $n$ besonder groot invloed op die sukses van gerekenariseerde stelsels het. Hierdie vyf is die volgende:

- Die akkuraatheid van die inligting wat deur die stelsels verskaf word.

- Die beskikbaarheid van hulpbronne.

- Die dienstyd van 'n bestuurder in die organisasie.

- Die tegniese kwaliteit van rekenaarpersoneel.

- Opleiding wat aan gebruikers van gerekenariseerde stelsels verskaf word.

Waar al die ander faktore die sukses positief beïnvloed het, was dit baie duidelik dat ' $n$ langer dienstermyn van bestuurders in die organisasie ' $n$ negatiewe invloed op die sukses van gerekenariseerde stelsels het (ander navorsers o.a. Lucas $^{5}$, het in die verlede dieselfde bevinding gehad). Hierdie veranderlike kan ook as 'n sogenaamde staatveranderlike waaraan niks gedoen kan word, beskou word. Aan al die ander veranderlikes kan daar sekerlik iets aan gedoen word deur die bestuur van 'n organisasie.

\section{'n Kostemodel}

Wanneer die bestuur van ' $n$ organisasie sy gerekenariseerde stelsels wil verbeter is die koste verbonde aan al elf veranderlikes (die staatveranderlike uitgesonder) van belang, maar bogenoemde vier is dié wat by voorkeur aandag behoort te geniet.

'n Beperking op die verbetering van die gerekenariseerde stelsels is uit die aard van die saak die hoeveelheid kapitaal wat daarvoor beskikbaar is. ' $n$ Verdere probleem is die feit dat die koste verbonde aan die verhoging van die verskillende veranderlikes van mekaar sal verskil. 'n Model ${ }^{1, p .230}$ is ontwikkel, geprogrammeer en met hipotetiese kostes getoets waarin daar weer van lineêre programmering gebruik gemaak is en waar daar 'n optimale oplossing vir die besteding van kapitaal aan die verskillende veranderlikes verkry kan word. (Onder optimale oplossing word verstaan die maksimum verbetering van die sukses van die gerekenariseerde stelsels onderhewig aan 'n koste beperking.)

\section{Samevatting on aanbevelings}

Wanneer gerekenariseerde inligtingstelsels in 'n organisasie misluk, word daar dikwels aanvaar dat die probleme bloot tegnies van aard is. In hierdie navorsingsprojek is daar aangetoon dat daar ook ander belangrike faktore bestaan wat ' $n$ bydrae tot die sukses of mislukking van 'n gerekenariseerde stelsel lewer.

Omdat dit die gebruiker is wat uiteindelik met 'n gerekenariseerde stelsel moet saamleef is dit belangrik om die sukses van so 'n stelsel te evalueer vanuit die gebruiker se oogpunt. Alle gebruikers kan ook nie oor dieselfde kam geskeer word nie omdat klerklike of transaksie-georiënteerde gebruikers op 'n heel ander vlak van 'n gerekenariseerde stelsel gebruik maak as byvoorbeeld bestuurders in 'n organisasie. Dit is verder ook baie belangrik om die rede vir 'n onsuksesvolle stelsel vas te stel voordat tegniese aspekte soos toerusting, programme, ensovoorts sonder meer daarvoor blameer word. Dan is dit ook noodsaaklik om die fondse wat beskikbaar is vir die verbetering van die gerekenariseerde stelsels op die mees doeltreffende wyse aan te wend.

In hierdie projek is daar deur middel van korrelasiemetodes eerstens vasgestel dat daar lineêre verbande tussen sekere faktore en die sukses van gerekenariseerde stelsels bestaan. Met behulp van stapsgewyse lineêre regressie en meervoudige lineêre regressie is die 12 belangrikste faktore geidentifiseer. Deur van 'n beperkte lineêre regressiemodel gebruik te maak, kon sommige van hierdie faktore verder elimineer word sodat die vyf faktore wat die grootste bydrae tot die sukses van gerekenariseerde stelsels lewer, geïdentifiseer kon word.

Dit is natuurlik belangrik hoe fondse aangewend moet word om die vlak van sukses van die stelsels optimaal te verhoog. Vir hierdie doel is 'n kostemodel waarin die kostebeperking in ag geneem is, geformuleer. Deur van hierdie model gebruik te maak behoort die bestuur van 'n organisasie in staat te wees om sy fondse op die mees doeltreffende wyse aan te wend vir die verbetering van sy gerekenariseerde stelsels. 


\section{Summary}

The central problem in this research project amounts to the fact that the design and implementation of computer-based information systems have for a long time (and in some organizations are still being) accepted as being primarily technical activities. As a result of this attitude about technology, the fact that practically all computer-based systems exist within the context of an organization has been largely ignored.

The aim of this study may be summed up in the four main points viz.:

(i) to investigate the use of computer-based information systems and their success as perceived by the user;

(ii) to determine which factors make the largest contribution to the success of computerized systems;

(iii) to determine, by means of optimizing methods which factors are the most important to change, so that the performance of the information systems may be optimally improved; and

(iv) to formulate a model which would enable the management of an organization to apply capital in such a way that the computerized systems may provide optimum performance.

By using a descriptive model of variables, and with the aid of BMDP statistical programs, correlation and regression methods as well as factor analysis were used to investigate linear relationships between certain variables and the success of computerized systems. In order to determine the relationships data from users of computerized systems in a very large organization were collected. In this organization there are about 140 computerized systems used by about 1200 clerical staff and 114 managers. Questionnaires were designed for the clerical workers as well as for the managers, and a random sample of 200 clerical users and the full population of managers were involved in the investigation. Most of the questions in the questionnaire could be answered on a 7-point scale. In this project user satisfaction was used as a measurement for the success of the various systems.

The managerial data were used to determine a linear regression model of variables in terms of which success could be explained. To be able to do this, the following method was used: by using factor analysis, the variables used to determine the success of the computerized systems were combined to form a single factor. Success could now be predicted by means of a linear relationship of a number of variables. With the aid of a stepwise linear regression computer program, the number of independent variables in terms of which success could be explained were reduced to
18 variables (the number at the outset had been 39 ). These variables explained $72 \%$ of the variation of the success variable. However, because there was a need for as simple a model as possible for the rest of the study, a multiple linear regression program was used to select the 'best' subset of independent variables in terms of which success could be explained; $69 \%$ of the variation in success could be explained by 12 variables.

A restricted linear regression model was formulated and solved with the available data. With this method it was possible to identify the five factors which have the most significant influence on the success of the computerized systems. These factors are the following:

- Accuracy of the information yielded by the systems.

- The availability of resources.

- The term of services of a manager within the organization.

- The technical quality of computer personnel.

- Training of users of the computer made available by computer personnel.

When the management of an organization know the reasons why their computerized systems fail, it is as important for them to know how to spend available funds in the most efficient way to improve the level of the success of the systems. For this reason a cost model in which the cost restriction was considered, was formulated as well. This model was programmed and tested with hypothetical costs. When solved, the solution provides an optimal way of applying monetary funds to improve the performance of the computerized systems

The procedure outlined above could well be used by the management of an organization when the performance of their computerized systems are poor. It is a systematic way of identifying the reasons for the failure as well as a welldefined method to use when decisions have to be made to improve the computerized systems.

\section{Verwysings}

1. Bruwer P.J.S.: Bydraes tot modelontwikkeling ten einde die werkverrigting van gerekenariseerde stelsels te evalueer. Ongepubliseerde proefskrif, PU vir CHO, Potchefstroom, 1982.

2. Dixon W.J. \& Brown M.B: BMDP-77, Biochemical Computer Pro grams, p-series. Berkeley, Los Angeles: Univ. of California Press, 1977.

3. Morrison D.F.: Multivariate Statistical Methods. New York: McGraw-Hill Book Company, 1976.

4. Frane J.W. \& Hill M.: Factor analysis as a tool for data analysis, Comm. Statist., Theory and Methods, Vol. A5, No. 6, 1976.

5. Lucas H.C. jr: Why Information Systems Fail. New York: Columbia University Press, 1975. 